\title{
Gambaran Perilaku Caring Petugas Lembaga Pembinaan Khusus Anak
}

\author{
Sri Maslihah, Muhammad Ariez Musthofa, Gemala Nurendah \\ Departemen Psikologi Fakultas Ilmu Pendidikan, Universitas Pendidikan Indonesia, Bandung \\ e-mail: maslihah_psi@upi.edu
}

\begin{abstract}
This study aims to obtain empirical data about caring behavior of warden in child prison (LPKA) perceived by child inmates called LPKA students. This study used mixed-method design combining quantitative and qualitative approaches. The first phase of research conducted by quantitative methods of data collection involving 67 samples consisted of 44 students of LPKA Bandung and 23 students of LPKA Tangerang. The measuring instrument used was caring behavior questionnaire adapted from Freese's caring instrument (1999). The second phase was conducted through interviews with four students of LPKA. The results showed that the caring behaviors of LPKA officers were mainly shown in the dimensions of understanding LPKA students. The caring behavior of these officers is demonstrated by their concern for physical conditions, food needs and emotional assistance, especially when LPKA students face problems. The presence of officers who care for LPKA students might be able to substitute the parents figures for LPKA students.
\end{abstract}

Keywords: caring, officer, LPKA student

\begin{abstract}
Abstrak
Penelitian ini bertujuan mendapatkan data empiris tentang gambaran perilaku caring petugas Lembaga Pembinaan Khusus Anak (LPKA) dalam persepsi anak didik. Penelitian ini menggunakan desain mix-methods yaitu penggabungan desain kuantitatif-kualitatif. Tahap pertama penelitian dilakukan pengumpulan data dengan metode kuantitatif yang melibatkan 67 sampel yang terdiri dari 44 orang anak didik LPKA Bandung dan 23 orang anak didik LPKA Tangerang. Alat ukur yang digunakan pada tahap kuantitatif adalah angket caring yang diadaptasi dari instrumen caring Freese (1999). Tahap kedua dilakukan wawancara kepada empat orang anak didik LPKA. Hasil penelitian menunjukkan perilaku caring petugas terhadap anak didik LPKA yang paling menonjol adalah pada dimensi memahami anak didik LPKA. Perilaku caring petugas ini ditunjukkan dengan adanya kepedulian terhadap kondisi fisik, kebutuhan pangan dan bantuan yang lebih bersifat emosional terutama pada saat anak didik LPKA menghadapi masalah. Kehadiran petugas yang caring kepada anak didik LPKA cukup mampu menggantikan figur orang tua bagi anak didik LPKA.
\end{abstract}

Kata Kunci: caring, petugas, anak didik LPKA

\section{Pendahuluan}

Kenakalan remaja saat ini semakin banyak dan sering terjadi di lingkungan masyarakat sekitar. Perilaku kenakalan seperti seks bebas, tawuran, penggunaan obat terlarang nampaknya sudah cukup melekat bagi remaja zaman sekarang bahkan sudah masuk kategori tindak pelanggaran hukum. Data di berbagai negara menunjukkan bahwa berbagai kenakalan remaja, akhirnya membawa mereka untuk berhadapan dengan aparat penegak hukum sehubungan tindak kenakalan dan kriminalitas yang dilakukan semakin hari menunjukkan peningkatan. Dalam hal ini mencakup anak-anak yang menjadi korban tindak kejahatan dari orang dewasa maupun sesama anak, anak yang menjadi pelaku tindak kejahatan atau pelanggaran hukum dan kelompok anak yang menjadi saksi dari suatu peristiwa yang berkaitan dengan tindak pelanggaran hukum.

Undang-Undang Sistem Peradilan Pidana Anak nomor 11 tahun 2012 Pasal 1 menyebutkan bahwa anak yang berhadapan dengan hukum adalah anak yang berkonflik 
dengan hukum, anak yang menjadi korban tindak pidana, dan anak yang menjadi saksi tindak pidana. Dalam pasal 69 UndangUndang Sistem Peradilan Pidana Anak disebutkan bahwa anak-anak yang dijatuhi pidana adalah anak-anak yang telah berusia 14 tahun sampai 18 tahun. Secara psikologis anak usia 14-18 tahun merupakan kelompok individu dalam tahap perkembangan remaja.

Muncie (1999) mengatakan bahwa hal utama yang menggarisbawahi munculnya penanganan khusus bagi anak-anak yang berhadapan dengan hukum adalah kesadaran bahwa anak-anak memerlukan respon yang yang berbeda dengan respon yang diberikan kepada orang dewasa yang melanggar hukum. Anak merupakan individu yang masih dalam proses tumbuh kembang sehingga memerlukan penanganan yang lebih khusus dan mendasar. Karenanya upaya pembinaan yang dilakukan seyogyanya tidak mengabaikan proses tumbuh kembang yang sedang dijalani anak.

Dalam Undang-Undang Nomor 11 tahun 2012 tentang Sistem Peradilan Pidana Anak (SPPA) terdapat lembaga-lembaga tempat anak menjalani masa pidananya, antara lain Lembaga Pembinaan Khusus Anak (LPKA), Lembaga Penempatan Anak Sementara (LPAS), dan Lembaga Penyelenggaraan Kesejahteraan Sosial (LPKS). Lembaga Pembinaan khusus anak (LPKA) yang dulu dikenal sebagai Lembaga Pemasyarakatan (LAPAS) Anak LPKA merupakan perwujudan kepedulian nyata negara untuk melindungi dan menghargai hak-hak anak sebagai anak bangsa yang berhak memiliki masa depan.

Data pada Kementerian Hukum dan HAM sampai April 2019 terdapat 2.430 anak yang berkonflik dengan hukum menjadi penghuni Lembaga Pembinaan Khusus Anak (LPKA) sebagai konsekuensi dari tindak pidana yang dilakukan anak. Meskipun di LPKA diberikan perlindunguan dan pendidikan, namun anak-anak ini harus menjalani perpisahan dengan lingkungan keluarga, sekolah dan teman-teman sebaya. Mereka juga harus kehilangan aktivitas sehari-hari sebelum mereka menjalani kehidupan di LPKA. Di saat anak-anak lain mengembangkan diri menuju kemandirian pribadi sebagai bekal masa dewasa, anak-anak di dalam LPKA justru harus menjalani kehidupan dalam tembok lembaga pemasyarakatan dan kehilangan kebebasan untuk berinteraksi secara fisik dengan masyarakat luas. Mereka harus menjalani kegiatan rutin dalam lingkungan yang terbatas secara fisik sehingga sangat memungkinkan munculnya rasa jenuh dan bosan.

Berdasarkan data dari bagian registrasi Lembaga Pembinaan Khusus Anak Bandung sampai dengan Mei 2019 menunjukkan bahwa sebagian besar anak binaan/ anak didik jarang mendapatkan kunjungan dari orang tua atau keluarga bahkan ada beberapa anak yang sejak masuk dan sudah beberapa bulan di LPKA tidak mendapat kunjungan keluarga. Hal ini sesuai dengan hasil penelitian menunjukkan rendahnya dukungan orang tua pada saat anak didik LPKA menjalani pembinaan di lembaga pemasyarakatan anak (Maslihah, 2015; Munthe dkk., 2017; Maslihah, 2017). Mayoritas anak didik di Lembaga Pembinaan Khusus Anak Bandung berasal dari keluarga golongan ekonomi bawah sehingga masalah faktor ekonomi menjadi salah satu alasan rendahnya kunjungan orang tua anak didik LPKA terutama mereka yang berasal dari luar kota Bandung karena kesulitan dalam biaya transportasi. Demikian pula berdasarkan kondisi keluarga, banyak anak didik datang dari keluarga dengan kedua orang tua berpisah dan anak dibesarkan dalam lingkungan keluarga besar. Meskipun demikian masih ada anak didik yang mendapat perhatian dari keluarganya (Maslihah, 2015).

Mengingat anak berada pada situasi hidup terpisah dari keluarga, maka diperlukan adanya dukungan sosial khususnya dukungan petugas LPKA. Dukungan petugas kepada anak didik LPKA yang diperlukan anak didik LPKA bukan semata-mata relasi formal. Sebaliknya relasi yang dibangun adalah relasi yang dapat 
membangun kedekatan personal yang menimbulkan rasa aman bagi anak. Kehadiran petugas dibutuhkan anak didik LPKA adalah menjadi sosok yang dapat diandalkan terutama saat anak mendapatkan masalah atau kesulitan ketika menjalani kehidupan di LPKA. Hal ini tidak terlepas dari bentuk konsekuensi perpisahan dengan orang tua, maka petugas diharapkan hadir sebagai figur pengganti orang tua yang dapat diandalkan anak saat menghadapi kesulitan (Maslihah, 2017).

Adanya kepedulian petugas atau pembina kepada anak didik, diharapkan dapat mengurangi tekanan psikologis sehubungan dengan keterpisahan dari orang tua atau keluarga sekaligus dapat menghadirkan sosok pengganti orang tua. Petugas memahami anak didik yang berada pada usia perkembangan remaja, yang tidak bisa diperlakukan sebagai orang dewasa maupun anak-anak. Petugas yang memperhatikan kebutuhan anak didik LPKA yang hidup terpisah dengan keluarganya, baik kebutuhan materi, fisik maupun kebutuhan psikologis. Adanya perhatian terhadap kondisi anak didik maupun upaya memberikan bantuan untuk memenuhi kebutuhan anak didik LPKA menunjukkan bentuk kepedulian terhadap orang lain, yang sangat dianjurkan dalam perspektif ethics of care.

Nel Noddings, seorang ahli filsafat pendidikan asal Amerika lulusan Stanford University School of Education memperkenalkan Ethics of care. Nel Noddings adalah seorang feminis yang menjelaskan lebih luas mengenai ethics of care dengan mengedepankan nilai-nilai yang terkait dengan perempuan (Mi'rojiah, 2012). Care yang dimaksud olehnya bukan semata-mata pemberian cinta dan kasih sayang secara universal kepada semua orang melainkan juga membutuhkan adanya hubungan kepada individu-individu tertentu (Banks, 2009). Noddings meyakini bahwa kepedulian yang didasarkan pada penerimaan, keterkaitan, dan responsivitas dapat menjadi landasan yang lebih baik dan mendasar secara etika (Noddings, 1984).
Karenanya Noddings (2012) sangat menekankan caring ini sebagai bagian dari etika dan moral yang dia sebut dengan "care ethics". Menurutnya care merupakan bagian penting dari hubungan guru dan murid. Orang dewasa dipandang sebagai penanggung jawab dan pembuat keputusan yang menentukan adanya hubungan ini. Menurut Noddings (2005) caring merupakan bentuk relasi yang dilihatnya paling baik. Noddings (2005) mendefinisikan hubungan yang memiliki caring sebagai "koneksi atau pertemuan antara dua manusia".

Kepedulian atau caring merupakan kata yang sulit didefinisikan karena memiliki makna banyak yaitu sebagai kata benda atau kata kerja, sebagai sesuatu yang dapat dirasakan, dan sebagai sikap atau perilaku (Berger \& Williams, 1992). Menurut Nurhastin (2012) caring merupakan sikap peduli, hormat, dan menghargai orang lain. Artinya, memberi perhatian dan mempelajari kesukaan seseorang dan bagaimana seseorang berpikir serta bertindak. Caring pada dasarnya menunjukkan satu orang peduli dengan perasaan orang lain yang umumnya orang menyebut hubungan seperti ini sebagai "empati" (Noddings, 2013).

Kajian Noddings tentang caring menunjukkan bahwa caring lebih mungkin terjadi secara alami pada tingkat pribadi khususnya dalam hubungan dengan keluarga atau teman. Meskipun demikian kajian caring ini dapat hadir dalam lingkungan profesional yang mungkin keterlibatan perasaan secara personal lebih sedikit dibandingkan dalam konteks keluarga (Noddings, 2012). Sebagaimana Crampton dan Turner (2014) sarankan bahwa kajian Noddings tentang caring tidak semata-mata dalam konteks hubungan keluarga, tapi dapat dikaji dalam isu-isu konteks profesional. Istilah caring ini sering digunakan dalam konteks profesional keperawatan yang mengutamakan nilai-nilai humanistik sebagai dimensi penyakit dan kesehatan atau dalam hubungan perawat dengan pasien yang sakit (Bayuo, 2018). 
Terkait lingkungan profesional konsep caring dalam konteks LPKA, akan ditujukan pada petugas sebagai pembina yang sekaligus akan menggantikan peran orang tua diharapkan memiliki perilaku caring sehingga diharapkan akan tumbuh perasaan positif pada anak didik LPKA sekalipun mereka harus hidup terpisah dari keluarga, teman dan lingkungan asal ataupun sekolah asal. Adanya perasaan positif ini sekaligus dapat mendorong kelanjutan proses perkembangan anak didik LPKA yang masih berada pada rentang usia kelompok remaja. Karena harus menjalani pembinaan di LPKA, menurut Granja dkk. (2014) anak dipaksa harus berpisah dengan orang tua khususnya ibu sehingga petugas menjadi mediator antara anak didik dengan orang tuanya. Tuntutan kehadiran peran keibuan bagi anak didik, memberi konsekuensi adanya dinamika emosi yang kompleks dalam hubungan petugas LPKA, orang tua yang dalam hal ini ibu dan anak didik. Oleh karena itu petugas LPKA yang menunjukkan perilaku caring khususnya terhadap kebutuhan anak didik pada dasarnya sejalan dengan prinsip pembinaan dan pendidikan bagi anak di LPKA yaitu prinsip ramah anak sebagaimana amanah Undang-Undang SPPA.

Caring dalam kajian Psikologi digunakan Benard (2004) sebagai bentuk interaksi orang tua dengan anak, yang disebut Benard dengan caring relationships yang merupakan salah satu faktor protektif dalam perkembangan seorang anak. Hal ini sejalan dengan Baker dkk. (1997) yang menyatakan bahwa dalam banyak teori perkembangan anak seperti teori Erickson dan Maslow berbicara penting caring relationships dalam relasi anak dengan lingkungannya khususnya relasi anak dengan orang tua. Dalam kajian Psikologi, perilaku caring dalam relasi orang tua dan anak secara konseptual umumnya menunjukkan sebagai pola asuh (Hidayah dkk., 2013; Tujuwale dkk., 2016).

Terkait perkembangan anak, Noddings (2010) menjelaskan bahwa ketika seorang anak aman dalam relasi dengan orang dewasa yang memiliki caring relationships, biasanya hal ini memiliki efek yang kuat pada anak.
Dalam hal ini orang dewasa yang tahu bahwa mereka akan bertindak sebagai model bagi anak/ anak didik akan memiliki tanggung jawab khusus. Mereka menunjukkan apa artinya caring dengan menunjukkan perilaku caring yang di dalamnya menunjukkan adanya perhatian. Orang dewasa yang tidak memiliki perilaku caring umumnya tidak menyadari bahwa tindakannya akan berdampak besar bagi perkembangan anak. Dalam hal ini anak yang sedang berkembang mungkin mereka secara sadar menolak perlakuan kejam yang mereka terima tetapi menginternalisasi cara-cara atau perilaku "tidak caring" atau tidak peduli yang ditunjukkan orang dewasa.

Dalam konteks pendidikan, menurut Ramberg dkk. (2019), caring dapat dikatakan mewakili tindakan yang baik dengan memperhatikan orang lain, termasuk dalam hal ini dari guru kepada siswa. Sementara Bulach dkk. (1998) menyatakan bahwa caring guru kepada anak didik mendorong anak untuk berprestasi karena dengan suasana nyaman yang diberikan guru, membuat anak didik tidak takut menghadapi kegagalan karena adanya guru siap membantu. Adapun hasil penelitian Wentzel (dalam Narinasamy, 2018) menunjukkan bahwa siswa memandang guru mereka memiliki caring, yaitu pada saat guru mendukung upaya sosial dan akademik mereka. Guru yang menunjukkan kepedulian pada siswa membuat siswa tertarik pada kegiatan akademik. Oleh karena itu, Wentzel menegaskan pentingnya memotivasi guru untuk memiliki caring dalam hubungan guru dengan siswa, khususnya siswa pada usia remaja. Bahkan Narinasamy (2018) menegaskan bahwa di sekolah, guru yang caring kepada siswanya memainkan peran penting dalam menanamkan nilai-nilai yang baik disamping memberikan pengetahuan dan keterampilan kepada siswa.

Selain itu caring yang diberikan guru menumbuhkan keyakinan pada anak didik bahwa dirinya memiliki kemampuan diperkuat dengan pujian yang diberikan guru saat anak berhasil mengerjakan tugas tertentu. Selanjutnya, Stronge (2007) 
mengatakan bahwa kondisi psikologis yang muncul dari interaksi yang menunjukkan adanya kepedulian (caring) guru pada siswa dapat memengaruhi prestasi siswa. Adapun Banks (2009) mengatakan bahwa kepedulian (caring) menunjukkan persepsi penerima. Menurutnya untuk menguji efektivitas komunikasi atau interaksi antara dua individu seringkali ditentukan oleh sikap yang dimiliki oleh penerima.

Lebih lanjut Hult (1979) menjelaskan peran yang harus dimiliki guru adalah berfokus pada peran yang harus dipenuhi oleh guru yang peduli. Menurutnya pada dasarnya terdapat guru yang peduli (caring) dan tidak peduli. Hult menjelaskan bahwa caring merupakan kegiatan yang bisa dilakukan guru dalam relasi dengan murid dan dapat dilakukan secara profesional. Hult merasa bahwa kita dapat melihat hubungan gurumurid dari perspektif tiga level pengakuan guru, yang menggabungkan pengaruh, perilaku dan dampak, antara lain: pertama, mengenali siswa sebagai individu yang unik. Kedua, mengakui siswa sebagai anggota umat manusia, dan ketiga, mengenali siswa dalam menjalankan perannya sebagai siswa. Untuk mengakui siswa sebagai unik, maka guru harus mampu memahami "bakat unik, kekhasan dan mungkin sejarah pribadi siswa". Adapun untuk memperlakukan siswa sebagai umat manusia, maka guru harus menghormati hak siswa. Selanjutnya untuk mengenali siswa dalam menjalankan perannya, maka guru harus menyediakan waktu untuk peningkatan pembelajaran siswa dan menilai kinerja siswa. Meskipun menurut Misbah dkk. (2015) penelitian mengenai persepsi siswa tentang perilaku caring guru, terutama pada hubungan interpersonal guru dengan siswa di kawasan Asia Tenggara sampai tahun 2015 masih relatif sedikit.

Kajian Hult (1979) tentang caring guru terhadap siswa merupakan kondisi yang selayaknya hadir dalam relasi petugas LPKA dengan anak didik LPKA. Relasi antara petugas dengan anak didik LPKA yang dibutuhkan menunjukkan relasi emosional yang menempatkan anak didik selayaknya anak lain yang sedang berkembang yang melahirkan pendekatan kemanusiaan. Perilaku caring seorang guru atau pembina dirasakan siswa saat guru berbicara tentang minat siswa dan kesediaan untuk mendengarkan keluhan siswa (Garza dkk., 2014). Sikap kepedulian yang dilakukan petugas kepada anak didik LPKA menunjukkan adanya relasi yang lebih bersifat pribadi, adanya respect kepada anak didik LPKA dan relasi yang manusiawi, menumbuhkan perasaan diperhatikan baik terkait kebutuhan sehari-hari maupun pengembangan diri (Maslihah, 2017).

Mengacu pada paparan di atas, terkait pembinaan anak didik LPKA dan dalam hubungannya dengan petugas sebagai pembina sekaligus pendidik anak didik LPKA peneliti tertarik mengkaji relasi petugas dan anak didik khususnya terkait perilaku caring petugas yang dipersepsikan anak didik dengan menggunakan konsep caring Hult (1979). Peneliti berasumsi bahwa perilaku caring merupakan salah satu implementasi dari dukungan sosial yang dikenal dalam Psikologi. Perilaku caring petugas sebagaimana dukungan sosial petugas merupakan hal penting dalam proses pembinaan anak didik LPKA. Petugas terutama yang menjadi wali anak didik LPKA seyogyanya mampu memahami anak didik sebagai individu yang berhak mendapat respect dan dalam kapasitasnya sebagai pembina dan pendidik petugas juga harus mampu mendukung proses pembinaan anak didik LPKA. Sebagaimana Undang-Undang nomor 11 tahun 2012 tentang Sistem Peradilan Pidana Anak (SPPA) pasal 86 bahwa anak yang ditempatkan di LPKA berhak memperoleh pembinaan, pembimbingan, pengawasan, pendampingan, pendidikan dan pelatihan. Demikian pula penjelasan pasal 85 menyebutkan bahwa hak yang diperoleh anak selama ditempatkan di LPKA diberikan sesuai dengan ketentuan Undang-Undang Pemasyarakatan. Dalam pemberian hak tersebut tetap perlu diperhatikan pembinaan bagi anak yang bersangkutan, antara lain mengenai pertumbuhan dan perkembangan anak baik fisik, mental maupun sosial. Pembinaan yang 
sejalan dengan pengasuhan yang seyogyanya diberikan orang tua kepada anak.

Mengingat konsep caring lebih dikenal dalam konteks pendidikan dan keperawatan, dalam penelitian ini peneliti mencoba mengkaji konsep caring Hult (1979) dalam relasi guru dan siswa, untuk diaplikasikan konsep caring ini dalam konteks relasi petugas dan anak didik LPKA. Untuk itu tujuan penelitian ini adalah mendapatkan gambaran persepsi anak didik LPKA terhadap perilaku caring petugas.

\section{Metode Penelitian}

Penelitian ini menggunakan desain penelitian mix-methods yaitu penggabungan desain kuantitatif-kualitatif. Creswell (2009) menyebut desain ini sebagai sequential explanatory design. Desain ini dicirikan oleh adanya pengumpulan data dan analisis kuantitatif pada fase pertama penelitian, kemudian diikuti oleh fase pengumpulan data kualitatif beserta analisisnya pada fase kedua yang dibangun berdasarkan hasil-hasil kuantitatif pada fase awal. Integrasi data dilakukan pada saat interpretasi atau tahap diskusi keseluruhan hasil studi. Dengan demikian rancangan penelitian ini dapat dijelaskan dalam gambar 1 .

Instrumen penelitian disesuaikan dengan pendekatan penelitian yang digunakan yaitu mix-methods. Pengumpulan data untuk desain kuantitatif menggunakan metode angket, sedangkan untuk kualitatif menggunakan wawancara. Untuk data kuantitatif dilakukan pengukuran perilaku caring dengan mengacu pada alat ukur perilaku caring yang diadaptasi dari instrumen caring Freese (1999) dengan reliabilitas $\quad 814$ Freese (1999) mengembangkan alat ukur caring yang mengacu pada konsep caring Hult (1979) yang terdiri dari 26 item mencakup tiga aspek caring, yaitu: memahami siswa, mengenal siswa, dan tidak mengabaikan siswa.

Pada tahap pertama, yaitu tahap penelitian kuantitatif, subjek penelitian berjumlah 67 anak didik LPKA yang telah menjalani pembinaan minimal 12 bulan, terdiri dari 44 orang anak didik LPKA Bandung dan 23 orang anak didik LPKA Tangerang. Setelah dilakukan analisis data kuantitatif, dilakukan penelitian tahap kedua, yaitu penelitian kualitatif untuk mendapatkan gambaran lebih mendalam tentang perilaku caring petugas LPKA kepada kelompok anak didik LPKA yang mempersepsikan perilaku petugas dengan kategori caring tinggi dipilih secara acak 2 (dua) orang anak didik LPKA Bandung dan 2 (dua) orang anak didik LPKA Tangerang. Analisis data yang dilakukan adalah analisis isi (content analysis) yang diperoleh dari wawancara.

\section{Hasil Penelitian dan Pembahasan}

Berdasarkan hasil data kuantitatif, dilakukan analisis deskriptif untuk memperoleh gambaran subjek penelitian melalui penyusunan norma kategori untuk variabel caring yang terbagi pada kategori tinggi, cukup tinggi, sedang dan rendah. Mengacu pada norma tersebut, dilakukan kategorisasi pada variabel caring untuk mendapat gambaran atau profil caring

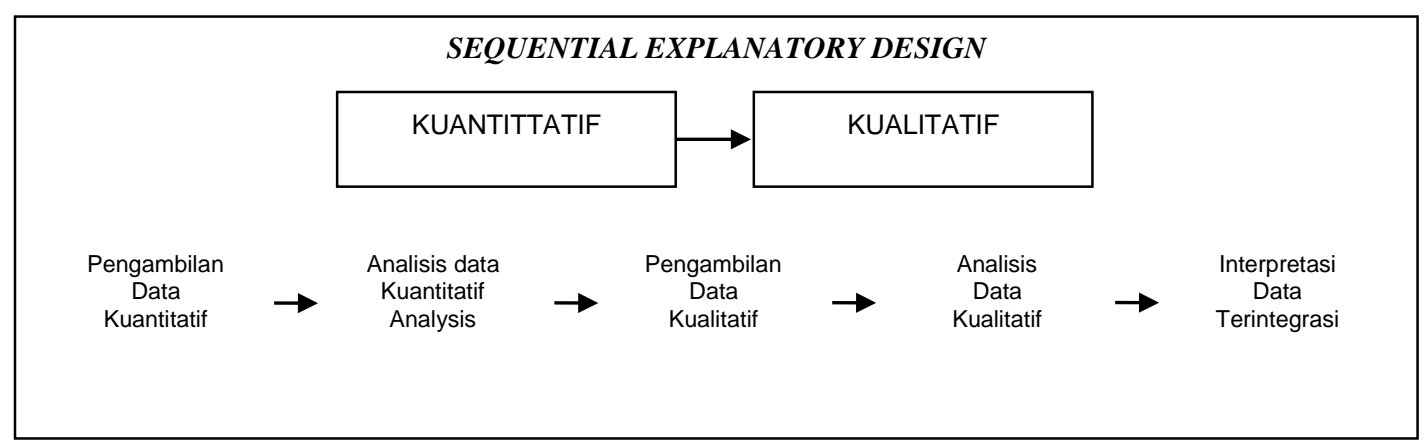

Gambar 1. Desain Penelitian 
petugas dalam persepsi anak didik LPKA. Gambar 2 menyajikan gambaran perilaku caring petugas LPKA.

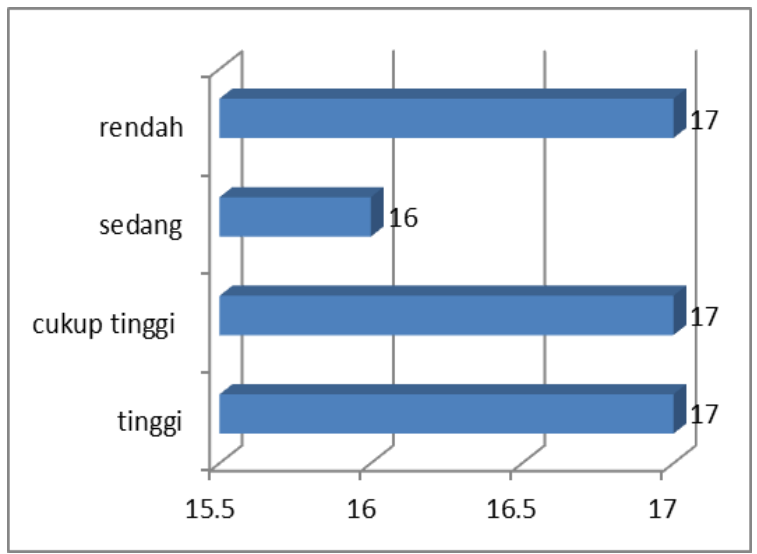

Gambar 2. Profil Perilaku Caring Petugas LPKA

Gambar 2 menunjukkan bahwa persepsi anak didik LPKA terhadap perilaku caring petugas menunjukkan persepsi yang beragam dan cukup merata antara yang mempersepsikan caring petugas terhadap anak didik termasuk kategori tinggi, cukup tinggi dan rendah, yaitu masing-masing 17 anak didik (25.4\%). Demikian pula yang mempersepsikan sedang hanya 16 orang $(23.9 \%)$.

Selanjutnya gambaran profil caring petugas yang dipersepsikan siswa berdasarkan nilai mean masing-masing dimensi caring, yaitu mengenal anak didik, memahami dan tidak mengabaikan anak didik dapat dilihat pada gambar 3 .

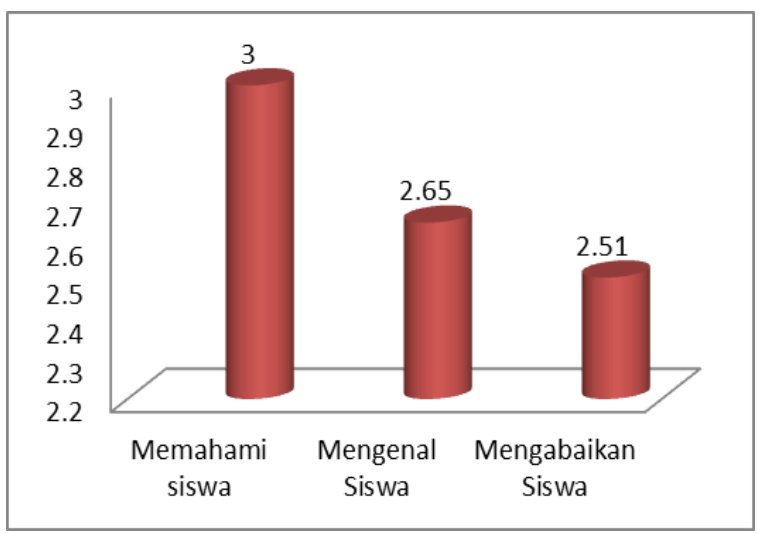

Gambar 3. Profil Perilaku Caring Petugas LPKA Berdasarkan Dimensi-Dimensi Caring
Data pada gambar 3 menunjukkan bahwa dimensi caring yang paling tinggi dipersepsi siswa adalah dimensi memahami siswa, artinya bagaimana kepedulian petugas yang dipersepsi anak didik LPKA adalah sikap petugas yang mampu memahami kondisi anak Dengan kata lain ada upaya pada diri petugas untuk menempatkan dirinya pada situasi anak sehingga petugas tidak selalu memaksakan kehendak ataupun tidak bersikap kaku dalam memperlakukan anak didik LPKA. Memahami anak didik pada dasarnya mencakup upaya petugas untuk memahami kebutuhan anak didik. Pertemuan antara kebutuhan anak didik dan sikap petugas ini menjadi dimensi caring yang paling menonjol yang dipersepsi anak didik LPKA.

Pada tahap kedua dilakukan wawancara kepada empat orang subjek yang memiliki persepsi perilaku caring petugas pada kategori tinggi. Hal ini mengacu pada tujuan penelitian ini untuk menggali lebih dalam perilaku caring petugas yang dipersepsi ataupun dihayati anak didik LPKA. Tabel 1 menunjukkan identitas subjek penelitian dan ringkasan wawancara dapat dilihat pada tabel 2 .

Hasil data kuantitatif yang diperoleh (gambar 2) pada dasarnya sejalan dengan data yang diperoleh dari penelitian kualitatif yang menunjukkan sebagian besar subjek mempersepsikan adanya perilaku petugas untuk memahami anak didik LPKA. Hal ini tampak dari adanya perilaku petugas dalam memfasilitasi anak untuk melakukan kontak dengan orang tua, memberikan hadiah yang memang dibutuhkan anak ataupun menyediakan waktu untuk mendengar keluh kesah anak didik. Dukungan yang diberikan petugas kepada anak didik LPKA tidak semata-mata karena tuntutan tugas, namun menunjukkan relasi emosional yang menempatkan anak didik selayaknya anakanak seusianya sedang berkembang yang melahirkan pendekatan kemanusiaan (Maslihah, 2017). 
Tabel 1

Identitas Subjek Penelitian

\begin{tabular}{|c|c|c|c|c|}
\hline Identitas Subyek & Subjek 1 & Subjek 2 & Subjek 3 & Subjek 4 \\
\hline Usia (tahun) & 18 & 16 & 19 & 19 \\
\hline Kasus & Pembunuhan & Pembunuhan & Pembunuhan & A susila \\
\hline Pendidikan terakhir & SMA & SMK & SMP & SMP \\
\hline Suku Bangsa & Sunda & Sunda & Betawi & Sunda \\
\hline Asal kota & $\mathrm{B}$ & $\mathrm{G}$ & B & \\
\hline Tinggal Bersama & $\begin{array}{l}\text { Kedua } \\
\text { Orang tua }\end{array}$ & Ibu & Kedua Orang tua & Kedua Orang tua \\
\hline $\begin{array}{l}\text { Hukuman yang harus } \\
\text { dijalani }\end{array}$ & $\begin{array}{l}5 \text { tahun } 2 \\
\text { bulan }\end{array}$ & 4 tahun 6 bulan & 9 tahun & 3 tahun 2 bulan \\
\hline $\begin{array}{lll}\text { Lama Pembinaan di } \\
\text { LPKA }\end{array}$ & $\begin{array}{l}2 \text { tahun } 1 \\
\text { bulan }\end{array}$ & 1 tahun & 3 tahun 3 bulan & 1 tahun 2 bulan \\
\hline
\end{tabular}

Tabel 2

Ringkasan Hasil Wawancara tentang Perilaku Caring Petugas LPKA

\begin{tabular}{cl}
\hline \multicolumn{1}{c}{ Subjek } & \multicolumn{1}{c}{ Perilaku caring petugas yang dipersepsikan } \\
\hline Subjek 1 & memberikan arahan, dorongan dan nasihat kepada anak didik \\
& memperhatikan kondisi fisik anak didik \\
& memberikan hadiah kepada anak didik baik makanan ataupun barang lain yang \\
& diperlukan anak didik \\
& memberikan waktu untuk mendengarkan masalah pribadi anak didik \\
& memperhatikan kondisi fisik anak didik \\
& memberi nasihat dan bimbingan khususnya rencana setelah keluar LPKA \\
& memberikan hadiah karena perilaku baik anak didik \\
& menanyakan kondisi keluarga subyek \\
& bersedia mendengar curahan hati anak didik \\
& memberikan nasihat dan mengingatkan perilaku positif yang hari dilakukan anak \\
& didik terutama masalah ibadah \\
& menanyakan kondisi fisik anak didik \\
& bersedia meluangkan waktu untuk bercanda , mendengar keluhan anak didik dan \\
& mampu menenangkan anak didik \\
& memfasilitasi anak didik bisa berhubungan dengan orang tua (meminjamkan \\
& handphone) \\
& memberikan arahan apa yang harus dilakukan di LPKA dan setelah keluar dari LPKA \\
& memperhatikan pemenuhan kebutuhan anak didik \\
& memperhatikan kondisi fisik anak didik \\
& menghargai anak didik sehingga tidak asal menyuruh anak didik tapi melihat kondisi \\
anak & \\
Subjek 4 &
\end{tabular}

Hal ini memperkuat temuan Hult (1979) dan Garza dkk. (2014) bahwa perilaku caring guru atau pembina yang dalam penelitian ini adalah petugas LPKA ditunjukkan dengan kemampuan petugas untuk memahami anak sebagai pribadi yang memiliki keunikan masing-masing dan secara manusiawi anak juga butuh didengar pikiran dan perasaannya atau kesediaan untuk mendengarkan keluhan siswa.

Menurut Nurhastin (2012) caring merupakan sikap peduli, hormat, dan menghargai orang lain. Artinya, memberi perhatian dan mempelajari kesukaan seseorang dan bagaimana seseorang berpikir serta bertindak. Adapun dalam konteks pendidikan, caring sebagaimana 
pandangan Nel Noddings dapat dimaknakan sebagai relasi yang berlandaskan penerimaan, keterkaitan dan responsivitas (Mi'rojiah, 2012). Dalam konteks penelitian ini, pemahaman petugas terhadap anak didik LPKA tidak bisa dilepaskan dari adanya penerimaan petugas terhadap anak didik LPKA dan adanya responsitivitas petugas termasuk dalam upaya membantu pemenuhan kebutuhan anak didik.

Hasil penelitian menunjukkan bahwa petugas LPKA tidak hanya memiliki kepedulian terhadap kondisi fisik anak, petugas juga berperilaku caring dengan mengontrol pemenuhan kebutuhan pangan anak-anak bahkan ada petugas yang cukup caring dengan memberikan pakaian (subjek 1 dan subjek 4). Hal ini mempertegas pendapat Noddings (1984) bahwa kepedulian (caring) merupakan upaya tatap muka dengan menanggapi kebutuhan orang lain dan sebagaimana Ramberg dkk. (2019) caring mewakili tindakan yang baik dari guru untuk memperhatikan siswanya, dalam konteks penelitian ini tindakan baik petugas kepada anak didik LPKA.

Perilaku caring petugas LPKA pada dasarnya merupakan salah satu dukungan petugas kepada anak didik LPKA. Dukungan petugas memiliki peranan penting bagi anak didik LPKA khususnya agar anak dapat menjalani pembinaan dengan baik dan mendorong perubahan positif pada anak (Maslihah, 2015). Adanya pemahaman petugas terhadap anak didik LPKA yang merupakan kelompok usia ini, yang harus berkembang dan membutuhkan perhatian dan bimbingan orang dewasa. Dari keempat subjek beberapa perilaku caring yang dipersepsikan perilaku caring petugas dan dirasakan subjek sebagai sikap orang tua kepada anak, diantaranya menunjukkan perhatian, memberikan bimbingan atau nasehat kepada anak didik LPKA, dan bersedia mendengarkan keluh kesah dan membantu mencari jalan keluarnya tidak terkecuali jika petugas harus mengeluarkan biaya sendiri (subjek 1). Hal ini sejalan dengan pendapat Nurhastin (2012), caring merupakan sikap peduli, hormat, dan menghargai orang lain. Artinya, memberi perhatian dan mempelajari kesukaan seseorang dan bagaimana seseorang berpikir serta bertindak.

Kajian Hult (1979) bahwa salah satu perilaku guru untuk guru mengakui siswa sebagai individu dengan keunikan pribadi adalah memahami sejarah atau latar belakang siswa. Dalam konteks relasi petugas LPKA degan anak didiknya, penelitian menemukan bahwa umumnya petugas LPKA berusaha mengetahui latar belakang remaja berdasarkan data yang ada pada bagian registrasi. Selanjutnya pada saat ada kunjungan keluarga, petugas melakukan komunikasi dengan orang tua anak didik. Bahkan di luar jam kunjungan beberapa orang tua mencari informasi tentang putranya yang sedang menjalani pembinaan di LPKA melalui petugas. Pada kondisi lain saat anak didik LPKA memerlukan kontak dengan orang tua, sesekali petugas memberi ijin anak didik menghubungi orang tuanya melalui handphone petugas dengan tujuan agar remaja merasa nyaman dalam menjalani masa pembinaan di LPKA (Maslihah, 2017). Petugas menunjukkan adanya pemahaman dan penerimaan petugas terhadap kondisi anak didik LPKA sehingga hal ini berpengaruh terhadap penyesuaian diri dan proses pembinaan anak didik di LPKA.

Penelitian terdahulu yang digali melalui wawancara kepada petugas ditemukan bahwa selain memberikan bimbingan dengan memberi nasehat kepada anak didik LPKA, petugas berusaha untuk membantu anak didik sehingga tidak mengalami rasa jenuh, sedih, dan memberikan kegembiraan kepada anak didik sehingga tidak jarang dari uang saku sendiri, petugas memberikan anak didik makananmakanan di luar menu yang disediakan pihak LPKA tentunya dengan memberi rasa senang kepada anak didik LPKA (Maslihah, 2017). Kondisi ini masih ditemukan dalam penelitian ini, yaitu adanya sarana yang diberikan petugas kepada anak didik LPKA untuk melakukan kontak dengan orang tua anak melalui telepon genggam. Hal ini 
umumnya dilatarbelakangi kondisi anak pada saat tertentu yang sangat membutuhkan kehadiran atau bantuan orang tuanya.

Selain itu ditemukan bahwa persepsi anak didik LPKA tentang perilaku caring petugas kepada anak didik menunjukkan adanya upaya petugas untuk menyenangkan anak didik LPKA dengan membelikan anakanak makanan jajanan sekolah yang tidak ditemukan di LPKA. Demikian pula sikap petugas yang akrab, bisa bercanda dengan anak didik memberikan kesenangan sekaligus ketenangan bagi anak karena melalui sikap yang akrab, bisa bercanda dengan petugas akhirnya menimbulkan kedekatan anak didik dengan petugas. Kondisi ini menunjukkan bahwa kepedulian (caring) petugas terhadap kondisi fisik anak didik, kebutuhan pangan anak didik dengan memahami perkembangan anak didik yang berada pada usia remaja. Selain itu ditemukan bahwa petugas mampu memberikan bantuan yang lebih bersifat emosional terutama pada saat anak didik LPKA menghadapi masalah yang seharusnya bisa mendapat bantuan dari orang tua. Kehadiran petugas yang menunjukkan caring kepada anak didik LPKA mampu mengganti kehadiran orang tua sehingga kedekatan petugas dan anak didik LPKA bisa terjalin.

Perilaku kepedulian (caring) yang dilakukan petugas kepada anak didik LPKA menunjukkan adanya relasi yang lebih bersifat pribadi, adanya respect kepada anak didik LPKA dan relasi yang manusiawi, menumbuhkan perasaan diperhatikan baik terkait kebutuhan sehari-hari maupun pengembangan diri. Bentuk dukungan ini bukan hanya menempatkan petugas sebagai teman bagi remaja-andikpas, namun sekaligus menunjukkan peran sebagai orang tua yang menciptakan relasi positif antara orang tua dan anak. Kepedulian (caring) merupakan sikap peduli, hormat, dan menghargai orang lain. Artinya, memberi perhatian dan mempelajari kesukaan seseorang dan bagaimana seseorang berpikir serta bertindak. Dalam kajian perkembangan remaja, Benard (2004) menyebutkan bahwa caring relationships orang tua dan anak dapat mengurangi munculnya perilaku berisiko pada remaja. Menurut Benard (2004) caring relationships sebagai faktor protektif bagi remaja tidak hanya dimunculkan dalam interaksi dalam keluarga, namun bisa diterapkan dalam interaksi remaja di sekolah.

Kepedulian (caring) bukan sekedar keterampilan teknis dalam sebuah proses pendidikan dan keberhasilan guru dalam proses pengajaran ditentukan oleh adanya karakteristik guru yang menunjukkan relasi yang bersifat psikologis yang ditunjukkan melalui komponen afektif, sosial maupun perilaku emosional, melebihi dari interaksi yang bersifat pedagogis dalam proses belajar mengajar baik di sekolah maupun masyarakat (Banks, 2009; Stronge, 2007). Banks (2009) mengatakan bahwa kepedulian (caring) menunjukkan persepsi penerima. Menurutnya untuk menguji efektivitas komunikasi atau interaksi antara dua individu seringkali ditentukan oleh sikap yang dimiliki oleh penerima. Hal ini sejalan dengan data penelitian ini yang menggali caring petugas melalui persepsi anak didik LPKA dan hasilnya menunjukkan bahwa dimensi memahami anak didik merupakan perilaku caring yang lebih banyak dipersepsi anak dan meskipun masih ada yang mempersepsi kategori caring petugas LPKA adalah rendah, namun lebih dari 50 persen anak didik LPKA mempersepsi caring petugas pada kategori tinggi dan cukup tinggi.

Undang-Undang nomor 11 tahun 2012 tentang Sistem Peradilan Pidana Anak (SPPA) pasal 85 dan pasal 86 tentang hak anak didik LPKA untuk memperoleh pembinaan, pembimbingan, pengawasan, pendampingan, pendidikan dan pelatihan sebagai upaya memfasilitasi pertumbuhan dan perkembangan anak didik LPKA. Temuan penetilian ini menunjukkan perilaku petugas yang ramah, perhatian, peduli, dan memberikan bimbingan kepada anak didik LPKA diperlukan anak untuk mengurangi tekanan sehubungan proses pembinaan yang harus dijalani anak di 
LPKA. Bahkan adanya kepedulian yang ditunjukkan petugas menempatkan mereka sebagai pengganti orang tua bagi anak didik LPKA sehingga anak tetap bisa mendapatkan haknya untuk tumbuh dan berkembang baik fisik, mental maupun sosial.

Gambaran perilaku caring petugas LPKA yang ditemukan dalam penelitian ini pada dasarnya sejalan dengan konsep Hult (1979) tentang caring dalam relasi guru dan siswa, yang mengacu pada tiga level, yaitu: 1) mengenali siswa sebagai individu yang unik dengan mengenali bakat dan latar belakang siswa; 2) mengakui siswa sebagai anggota umat manusia sehingga guru mampu menghormati dan menghargai hak siswa; dan 3) mengenali siswa dalam perannya sebagai siswa. Sebagaimana disebutkan pada bagian pendahuluan bahwa penelitian ini menggunakan konteks yang berbeda, yaitu dengan mengimplementasikan konsep Hult dalam konteks LPKA, khususnya dalam relasi petugas LPKA dan anak didik LPKA. Temuan-temuan dalam penelitian tentu berbeda dengan konteks relasi guru dan siswa. Mengacu pada hasil penelitian ini, perilaku caring petugas terhadap anak didik yang dijaring melalui persepsi anak didik LPKA lebih mendekati pada level 1 dan level 2 dari konsep caring Hult (1979), yaitu mengenali anak didik/ siswa sebagai individu yang unik dan mengakui siswa sebagai umat manusia sehingga siswa merasa dihargai dan dihormati haknya. Hal ini tampak dari temuan penelitian kualitatif bahwa caring petugas yang dipersepsikan anak didik lebih menunjukkan relasi yang bersifat pribadi yang menunjukkan adanya dukungan emosional yang diberikan petugas. Meskipun dalam penelitian ini petugas memberikan dukungan material, seperti memberikan makanan bahkan ada yang memberikan uang saku namun dampak yang muncul dari perilaku petugas adalah relasi emosional antara petugas dan anak didik sehingga kedekatan personal bisa terjalin antara keduanya. Kondisi ini mendukung temuan penelitian sebelumnya bahwa adanya kedekatan emosional dan rasa dihargai yang muncul pada anak didik LPKA memberi pengaruh besar bagi kesejahteraan psikologis anak didik (Maslihah, 2015; 2017).

Keterbatasan utama penelitian ini adalah tidak digunakannya konsep caring dalam perspektif Psikologi. Meskipun Crampton dan Turner (2014) menyarankan bahwa kajian Noddings tentang caring tidak semata-mata dalam konteks hubungan keluarga, tapi dapat dikaji dalam isu-isu konteks profesional. Sejauh ini peneliti belum menemukan konsep caring dalam perspekstif psikologi. Penelitian ini merupakan upaya mengadopsi teori pendidikan, khususnya caring guru dalam relasinya dengan siswa dengan mengimplementasikan dalam konteks relasi petugas LPKA dengan anak didik LPKA disertai mengkaji perilaku caring petugas LPKA sebagai figur pengganti orang tua bagi anak didik LPKA.

\section{Simpulan}

Perilaku caring petugas LPKA pada dasarnya merupakan salah satu dukungan petugas kepada anak didik LPKA. Meskipun perilaku caring yang dipersepsikan anak didik LPKA dalam penelitian ini lebih menunjukkan adanya perilaku yang menunjukkan relasi yang lebih bersifat personal dan mengembangkan relasi emosional antara petugas dan anak didik LPKA, pada dasarnya temuan dalam penelitian ini sejalan dengan konsep caring Hult (1979) dalam konteks relasi guru dan siswa.

Persepsi anak didik Lembaga Pembinaan Khusus Anak (LPKA) terhadap perilaku caring petugas bersifat subjektif dan bervariasi. Terdapat kelompok anak yang mempersepsikan perilaku caring petugas terhadap anak didik LPKA tergolong rendah dan ada pula yang mempersepsikan perilaku caring petugas kepada anak didik LPKA dapat dikategorikan tinggi. 
Temuan dari penelitian ini diharapkan memberikan informasi khususnya bagi petugas LPKA dalam menjalankan proses pembinaan anak didik LPKA sehingga pembinaan yang dilakukan dapat sejalan dengan pemberian upaya pemenuhan hak anak didik untuk tumbuh dan berkembang sesuai usia perkembangannya.

\section{Daftar Pustaka}

Baker, J. A., Terry, T., Bridger, R., \& Winsor, A. (1997). Schools as caring communities: A relational approach to school reform. The School Psychology Review, 26, 586-602.

Banks, C. (2009). Caring teachers and their impact: A phenomological study of students' perceptions. ProQuest LLC.

Bayuo, J. (2018). The last bath": A reflexive ethnography of caring for a prisoner-patient. International Journal for Human Caring, 22(1). http://dx.doi.org/10.1891/10915710.22.1.

Benard, B. (2004). Resiliency: What we have learned. WestEd.

Berger \& Williams. (1992). Fundamental of nursing: Collaborating for optimal health. Apleton \& Lange.

Bulach, C., Brown, C., \& Potter, L. (1998). Behaviors that create a caring learning community. Journal for a Just and Caring Education, 4, 441-453.

Crampton, R., \& Turner, S. (2014). Caring for prisonerspatients: A quandary for registered nurses. Journal of PeriAnesthesia Nursing, 29(2), 107-118. http://dx.doi.org/10.

1016/j.jopan.2013.03.012

Creswell, J. W. (2009). Research design pendekatan kualitatif, kuantitatif, dan mixed, edisi ketiga. Pustaka Pelajar.

Freese, S. (1999). The relationship between teacher caring and student engagement in academic high school clases. ProQuest, UMI Dissertations Publishing, 9933931.

Garza, Rubén, Alejandro, E. A., Blythe, T., \& Fite, K. (2014). Caring for students:
What teachers have to say. https://www.researchgate.net/publicatio n/ 275473235

Granja, R., Cunha, M. I. P., \& Machado, H. (2015). Mothering from prison and ideologies of intensive parenting: Enacting vulnerable resistance. Journal of Family Issues, 36(9) 1212-1232. https://doi.org/10.1177/0192513X14533 541

Hidayah, R., Yunita, E., \& Utami, Y. W. (2013). Hubungan pola asuh orang tua dengan kecerdasan emosional anak usia prasekolah (4-6 Tahun) di TK Senaputra Kota Malang. Jurnal Keperawatan, 4(2). https://doi.org/10.22219/ jk.v4i2.2363

Hult, R. E. Jr. (1979). On pedagogical caring. Educational Theory, 29, 237244.

Maslihah, S. (2015). Faktor-faktor yang mempengaruhi kesejahteraan subyektif anak didik lembaga pemasyarakatan anak (Makalah pada seminar nasional penelitian dan pengabdian). Universitas Islam Bandung.

Maslihah, S., \& Urie, B. E. (2016). Pengaruh spiritualitas dan dukungan orang tua terhadap kesejahteraan psikologis lembaga pembinaan khusus anak (Laporan hasil penelitian tidak diterbitkan). Universitas Pendidikan Indonesia.

Maslihah, S. (2017). Strategi koping dan dukungan petugas terhadap kesejahteraan integratif anak didik lembaga pembinaan khusus anak (Disertasi tidak diterbitkan). Universitas Padjadjaran Bandung,

Mi'rojiah, K. (2012). Ethics of care dalam pendidikan: sebuah analisis filosofis atas pemikiran Nel Noddings (Skripsi tidak diterbitkan). Universitas Indonesia.

Misbah, Z., Gulikers, J., Maulana, R., \& Mulder, M. (2015). Teacher interpersonal behaviour and student motivation in competence-based vocational education: Evidence from 
Indonesia. Teaching and Teacher Education, 50, 79-89.

Muncie, J. (1999). Institutional tolerance: Youth justice and the 1998 crime and disorder act. Critical Social Policy, 19(2), 147-175.

Munthe, B., Maslihah, S., \& Chotidjah, S. (2017). Hubungan spiritualitas dan psychologycal well-being pada anak didik pemasyarakatan di lembaga pemasyarakatan kelas IIA Tangerang Jurnal Psikologi Klinis Indonesia, 1(1), 53-65.

Narinasamy I., \& Mamat, W. H. W. (2015). Caring teacher in developing empathy in moral education. Mojes: The Malaysian Online Journal of Educational Science, 1(1).

Narinasamy, I. (2018). The need to care: students' perceptions on teacher's caring behaviour (Conference Paper). Conference Asia-Pacific Network for Moral Education. https://www.researchgate.net/publicatio $\mathrm{n} / 326668365$

Noddings, N. (1984). Caring: A feminine approach to ethics and moral education (2nded.). University of California Press.

Noddings, N. (2005). The challenge to care in schools: An alternative approach to education (2nd ed.). Teachers College Press.

Noddings, N. (2010). Moral education in an age of globalization. Educationa: Philosophy and Theory, 42(4), 390396. https://doi.org/10.1111/j.14695812.2008.00487.x

Noddings, N. (2012). The caring relation in teaching. Oxford Review of Education, 38(6), 771781. http://dx.doi.org/10. 1080/03054985.2012.745047

Noddings, N. (2013). Caring: A relational approach to ethics and moral education $\left(2^{\text {nd }} e d\right.$.). University of California Press.

Nurhastin. (2012). Realisasi cinta sang guru dalam mendidik siswa. http://sumsel.kemenag.go.id.

Ramberg, J., Låftman, S. R., Almquist, Y. B., \& Modin, B. (2019). School effectiveness and students' perceptions of teacher caring: A multilevel study. Improving Schools, 22(1), 55-71. https://doi.org/10.1177/1365480218764 693

Stronge, J. H. (2007). Qualities of effective teachers (2nd ed.). Association for Supervisors and Curriculum Development.

Tujuwale, A., Rottie, J., Wowiling, F., \& Kairupan, R. (2016). Hubungan pola Amurang. Jurnal keperawatan, 4(1). https://doi.org/10.22219/ jk.v4i2.2363

Undang-Undang Republik Indonesia nomor 11 tahun 2012 tentang Sistem Peradilan Pidana Anak. Sistem Database Pemasyarakatan.

http://smslap.ditjenpas.go.id/public/ arl/current/ monthly 
Psympathic, Jurnal Ilmiah Psikologi Desember 2019, Vol. 6, No. 2, Hal. : 241-254 